foot of that part of the Cordilleran mountain series called Sierra de Sandia and bordering exactly the Rio Grande del Norte; just where is situated the town of Albuquerque and the villages of Alameda, Sandia and Bernalillo.

Such erroneous volcanic geography has never been given in a map of the United States even on the most rough. sketch.

The group of craters of the Cerrito was first discovered by the present writer in 1853 , and recorded as such, on the geological map of New Mexico, 1857, published in Zurich, Switzerland, in Geology of North America. They occupy a part of the mesa existing between the southern system of the Cordillera called the Santa Fé Mountains and the northern end of the Sierra de Sandia, nearer to the city of Santa Fé than of Albuquerque, and close to the railroad station called Lamy. The Cerrito lie between Galisteo, Cieneguilla and Lamy. On the sketch map of Mr. Hill, the crater of the old volcano called Cerrito ought to be placed just near the head waters of the Rio Pecos, a little south of the Santa Fé Mountains and northeast of the Sierra de Sandia; and the three black dises of Albuquerque, Sandia and Bernalillo, on the eastern side of the Rio Grande, scratched out.

\section{Jules MARCoU.}

\section{GLACIAL STRIA.}

To THE Editor OF SCIENCE: While strolling over the low hills adjacent to the Delaware river in Northampton county, Pa., I found unmistakable glacial striæ, at least four miles south of the front of the terminal moraine, as commonly defined.

Three parallel scratches, with traces of a fourth, on the sloping side of a shelf of limestone that had just been uncovered from under what seemed a slight bed of true till, and with a direction S. 20 W., made a mistake of judgment, it seems to me, impossible. The repeated occurrence of such ice traces throughout this county to a distance of at least twenty miles south of the moraine most certainly opens for investigation the question of the southern limit of glacial ice.

$$
\text { Yours, }
$$

Albert G. RaU.

BeTHLEHEM, September 15, 1897.
THE ALLEGED EXTINCTION OF LINES OF DE. SCENT.

Professor W. K. Brooks contributed to this JoURNAL some time since (February 1, 1895) an interesting article entitled 'An Inherent Error in the Views of Galton and Weismann on Variation.' The argument of this paper was based on the alleged necessary extinction of lines of descent. Thus Professor Brooks writes :

"Of all the individuals of a species which lived at a given period, very few would have descendants at a later period." "Most of the individuals in each generation must fail to perpetuate their lines to remote descendants." "If a city like Baltimore, where the strangers to each one of us outnumber our acquaintances a thousand fold, could be quarantined against people from outside for a thousand years, each generation would be like the present one so far as known relations are concerned, although at the end of the period the inhabitants would certainly not be descended from the Baltimorians of our day, but from only a very few of them. Most of our lines would be extinct."

I return to the subject because Professor Brooks' statements carry great weight in a subject important for theories of heredity and evolution, and it seems to me that they contain 'an inherent error.' Family names will become extinct, as shown by Mr. Galton, but not lines of descent that have persisted for several generations. If the present population of Baltimore is to remain stationary, some of the inhabitants having no offspring, the others must on the average have more than two. If, for example, we simplify the problem by supposing one-half of the population to be sterile, and each of those who are fertile to have four offspring who survive to maturity, then only onesixteenth of the fertile parents would have no descendants in the third generation. Of the balance only one line in 256 would become extinct in the fourth generation, one in 65,536 in the fifth, and one in $4,294,967,296$ in the sixth. With families of variable size, etc., the calculations would become intolerably complex; but in any population not decreasing in numbers the descendants of each individual tend to increase in a geometrical ratio and cannot become extinct after several generations. If King Alfred and King Alfred's barber had lines of descent lasting several generations, we are each 
descended from both of them; or, if not, our descendants (should we have them) will be.

Genealogies are not, as Professor Brooks states, ' represented by a slender thread of very few strands,' but by the branching tree to which he objects, except that there are many trees whose branches interlace and anastomose.

\section{J. McKeen CAttell.}

CoLUMBIA UNIVERSITY.

\section{SCIENTIFIC LITERATURE.}

RECENT BOOKS ON PHYSICS.

Modes of Motion. By A. E. DolbEar. Boston, Mass., Lee \& Shepard. $12 \mathrm{mo} .120 \mathrm{pp}$.

The second title of Professor Dolbear's little book is 'Mechanical Conceptions of Physical Phenomena.' It is essentially a popular presentation of the fundamental properties of matter as contrasted with those which the author assumes the ether to possess. Matter is contrasted with ether in reference to a series of twenty-two of its commonly recognized attributes, in nove of which are the two found identical, and in the great majority of cases they are declared to be directly opposed to each other. Indeed the author makes special effort to demonstrate the absolute dissimilarity of matter and ether, and in so doing even goes so far as to declare that the latter in no way affects the senses. But he evidently believes in the possibility of transforming ether into matter and matter into ether and the indestructibility of matter or the impossibility of transmitting the elements he regards as tentative assumptions. A few sentences are devoted to a consideration of the origin of the ether itself, but the author finds quick refuge in the easy 'assumption that it was in some way and at some time created,' this being, he declares, more rational than to assume that it always existed. The book will be found readable and interesting by students of physical science.

Deductive Physics. By Frederick J. Rogers, M.S. Ithaca, New York, Andrews \& Church. 8vo. $250 \mathrm{pp}$.

This book deserves consideration by all who are seeking a satisfactory college text-book of physics. It is in many respects different from any of the almost innumerable candidates for this distinction that have appeared during the past decade. Of these nearly every one has its merits and all have faults, but the variety is so great that the special necessities of almost every situation can be satisfied. There has been, however, a regrettable tendency in two directions. On the one hand, there have appeared several treatises very complete, very well prepared, but so large as to be really formidable and quite impossible of mastery in the time usually allotted to this subject in the college curriculum. The use of these compelled the adoption of the plan of omitting or 'skipping' many pages or even chapters, which is by no means to be commended under all circumstances. On the other hand, many college text-books are offered in which laboratory exercises are made so prominent as to seriously interfere with and often absolutely prevent a proper appreciation of the 'theory of physics.' Within a few years a few books have made their appearance in which both of these evils have been largely avoided and in which it has been attempted, as in the volume under consideration, 'to present, in compact though logically complete form, the principal facts, laws, definitions and formulas of the science of physics.' In the present instance the author has enjoyed a large measure of success. His definitions of fundamental terms and principles are, in the main, sound and discriminating. Although the discussions are generally concise, they are generally satisfactory, and no important phase of the subject has been entirely omitted. The illustrations are diagrammatic and clear and the leading propositions are illustrated and enforced by well-selected problems. No attention is given to experimental or laboratory exercises, but it is assumed that these accompany the use of the book whenever possible. In the opinion of the writer the author has made a mistake, unfortunately not an extremely uncommon one, in introducing several unauthorized and not generally recognized names for derived units, such as $\mathrm{kin}$, gramkin, spoud, etc. This tendency towards multiplication of unit names has little to commend it and there is serious objection to it. It was the unanimous decision of the Chamber of Delegates of the International Electric Congress of 1893 that in electricity and magnetism 